\title{
Fulminant toxoplasmosis presenting as isolated myelitis
}

\section{Toxoplasmose fulminante se apresentando como mielite isolada}

Leonardo Favi BOCCA', Alexandre Israel Kochi SILVA', Carlos Roberto Veiga KIFFER², Sergio CAVALHEIRO', Paulo Eduardo Tavares de OLIVEIRA', João Norberto STAVALE ${ }^{3}$, Linus Jan NO ${ }^{3}$, Franz Jooji ONISHI ${ }^{1}$

A 29-year-old male patient with an untreated HIV infection for seven years presented with a two-month history of neck pain, progressive left-hand weakness and numbness. Physical examination showed C5-C6 territory hypoesthesia and urinary bladder retention. A spinal MRI (Figure 1) showed a single contrast-enhanced lesion at C4-C6 level, cerebrospinal fluid analysis showed 3.6 white blood cells $/ \mathrm{mm}^{3}$ and a positive IgG for toxoplasma. Despite empiric treatment, the disease progressed locally and to the brainstem. Autopsy (Figure 2) showed disseminated CNS toxoplasmosis.

Toxoplasmosis is the most common CNS infection in patients with AIDS, but isolated spinal cord involvement is rare $^{1}$. Prompt empiric treatment for toxoplasmosis should be considered in all patients ${ }^{2}$.

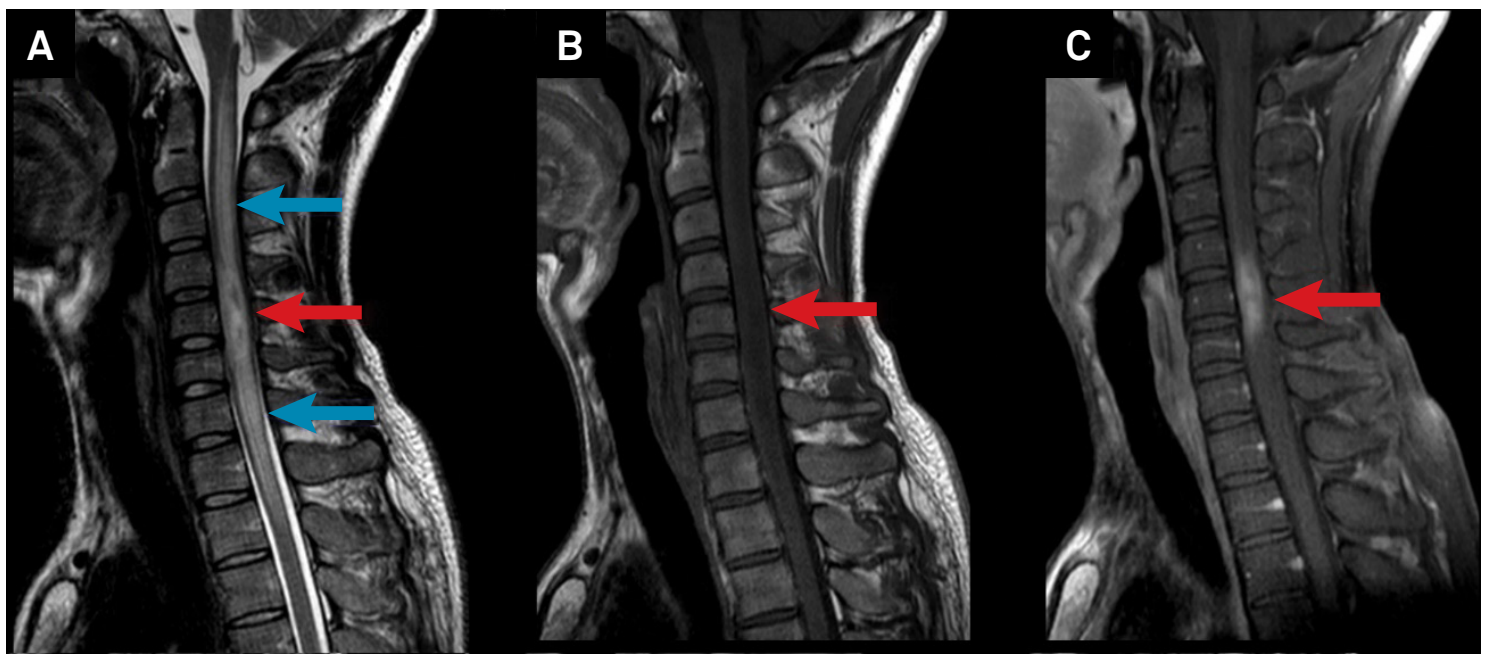

Figure 1. (A) Sagittal T2-weighted cervical spine MRI showing a heterogeneous mass-occupying lesion in the spinal cord (red arrow) with longitudinal edema from the medulla to T2 (blue arrows). The same lesion in T1-weighted MRI without (B) and with contrast (C). Note the heterogeneous contrast enhancement of the lesion (red arrows on B and C).

\footnotetext{
${ }^{1}$ Universidade Federal de São Paulo, Departamento de Neurologia e Neurocirurgia, São Paulo SP, Brasil;

${ }^{2}$ Universidade Federal de São Paulo, Departamento de Medicina, São Paulo SP, Brasil;

${ }^{3}$ Universidade Federal de São Paulo, Departamento de Patologia, São Paulo SP, Brasil.

Leonardo Favi Bocca (iD https://orcid.org/0000-0003-4809-0159;Alexandre Israel Kochi Silva iD https://orcid.org/0000-0001-8541-949X; Carlos Roberto Veiga Kiffer iD https://orcid.org/0000-0003-1122-0693; Sergio Cavalheiro iD https://orcid.org/0000-0002-9750-0508; Paulo Eduardo Tavares de Oliveira (iD) https://orcid.org/0000-0002-5196-4753; João Norberto Stavale iD https://orcid.org/0000-0002-9141-0106; Linus Jan No iD https://orcid.org/0000-0002-3036-7626; Franz Jooji Onishi iD https://orcid.org/0000-0002-5641-5104

Correspondence: Franz Jooji Onishi; Disciplina de Neurocirurgia da UNIFESP; Rua Napoleão de Barros, 715, $6^{\circ}$ andar, São Paulo SP, Brasil:

E-mail: neurocirurgia@gmail.com

Conflict of interest: There is no conflict of interest to declare.

Received 22 March 2019; Received in final form 02 June 2019; Accepted 16 July 2019.
} 


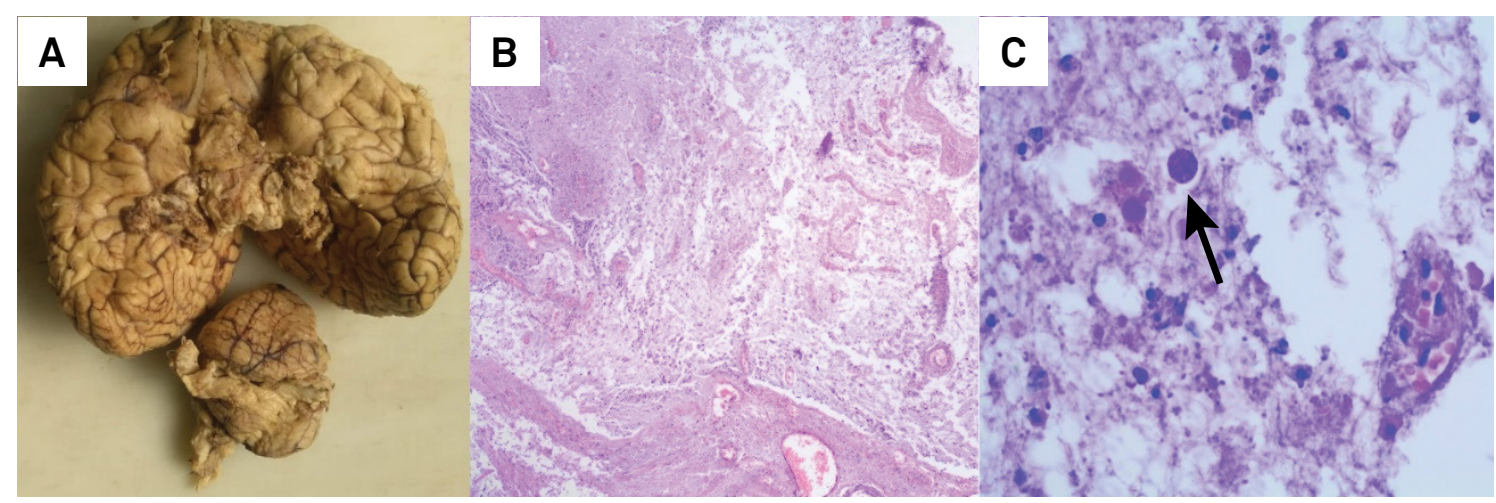

Figure 2. Autopsy findings showing: (A) macroscopic brain appearance with necrosis of brainstem and loss of connection between it and cerebellum. Histological evaluation with hematoxylin and eosin stain showed vast areas of liquefactive necrosis (lower magnification, B) and some T. gondii bradyzoites at higher magnification (arrow, C).

\section{References}

1. Vyas R, Ebright J. Toxoplasmosis of the spinal cord in a patient with AIDS: case report and review.

Clin Infect Dis. 1996 Nov;23(5):1061-5.

https://doi.org/10.1093/clinids/23.5.1061
2. García-García C, Castillo-Álvarez F, Azcona-Gutiérrez JM, Herraiz MJ, Ibarra V, Oteo JA. Spinal cord toxoplasmosis in human immunodeficiency virus infection/acquired immunodeficiency syndrome. Infect Dis. 2015 May;47(5):277-82. https://doi.org/10.3109/00365548.2014.993421 